\title{
Parental Involvement in Curriculum Implementation as Perceived by Nigeria Secondary School Principals
}

\author{
Eyiuche Ifeoma Olibie ${ }^{1}$ \\ ${ }^{1}$ Department of Educational Foundations, Nnamdi Azikiwe University Awka, Anambra State, Nigeria \\ Correspondence: Eyiuche Ifeoma Olibie, Department of Educational Foundations, Nnamdi Azikiwe University \\ Awka, Anambra State, Nigeria. Tel: 234-080-3552-7391. E-mail: utchackonsults@yahoo.co.uk
}

Received: November 30, 2013

Accepted: December 19, 2013 Online Published: February 12, 2014

doi:10.5539/jel.v3n1p40

URL: http://dx.doi.org/10.5539/jel.v3n1p40

\begin{abstract}
The purpose of this study was to assess the extent to which parents are involved in curriculum implementation in secondary schools in Anambra State of Nigeria as perceived by male and female principals. A research question and a hypothesis were formulated to guide the study. The survey research design was used. Participants were 257 secondary school principals. A 16-item researcher-developed questionnaire, designed on a 4-point scale, was used to collect data. Structured interviews were also used. Mean scores, content analysis, frequencies and t-test were used for data analysis. Findings indicated that in the opinions of male and female principals, there was a little extent of parental involvement in curriculum implementation. This indicates that irrespective gender, the principals in this study held a similar view of a little extent of parental involvement to curriculum implementation in schools. For this trend to improve, school principals and teachers need to make efforts for reaching and involving members to support curriculum implementation. They should design and implement strategies that will result in improved involvement, and at the same time, balance involvement vis-à-vis educators' professional autonomy.
\end{abstract}

Keywords: curriculum implementation, secondary education, parental involvement

\section{Introduction}

\subsection{Background to the Problem}

Education is one experience that most children worldwide have in common and the most common means by which societies prepare their young for the future. The underlying goal of all education is to create a positive change in the student's knowledge, achievement, and behavior. Education is not just about getting children into school, but making sure that all schools work in the best interest of the children entrusted to them. Schools provide various learning experiences that prepare children for future living. At the heart of these learning experiences is the curriculum.

The word "curriculum" comes from the Latin word "currere" which means "a course to be run". By this definition, curriculum signifies a course of studies followed by students in a teaching institution. It refers to a course or courses through which learning takes place. In formal education, a curriculum is the set of courses, course work, and content offered at an educational establishment. A curriculum is a "plan or program of all experiences which the learner encounters under the direction of a school" (Tanner \& Tanner, 1995, 158). According to Gatawa $(1990,8)$, it is "the totality of the experiences of children for which schools are responsible". The curriculum is a tool that describes the teaching, learning, and assessment materials available for each specific course of study. As stated by Department for Education (2010), curricula usually define the learning that is expected to take place during a course or programme of study in terms of knowledge, skills and attitudes. It also specifies the main teaching, learning and assessment methods and provides an indication of the learning resources required to support the effective implementation of the course. It includes a consideration of the purposes of education, the content of teaching, teaching approaches with the focus being on the product as well as the process and a programme of evaluation of the outcomes. This implies that one of the functions of a curriculum is to provide a template or design which enables learning to take place. The curriculum generally delineates what educational objectives, content, learning experiences and outcomes of learning involve (Sowetll, 2000; Esu, 2005). Through the curriculum, the citizens of a nation are made to ultimately develop an understanding and appreciation of knowledge, learning and interaction with education. The curriculum thus 
affects, effects and is affected somehow by the purposes, structures and contents of the wider society. It provides the education system with an opportunity to respond to the contextual requirements of the times, to address a number of major problems in the present education system, and to ensure that current conceptions of learning, progression and knowledge are built into education.

The place of curriculum in education makes it axiomatic that concerted efforts be made at all times to implement a curriculum that meets the needs of the society. Ornstein and Hunkins (1998) note that curriculum implementation focuses on the processes and practices through which a curriculum is implemented. Nnadozie (2004) defines curriculum implementation as the execution of relevant curriculum and teaching tasks within and outside the school setting. The task of curriculum implementation as described in Thomas (2012) involves putting into practice the stipulated curriculum policies, content and innovations. Curriculum implementation involves the performance of teaching tasks and rendering of expected services as specified in the curriculum. It is the process of curriculum delivery. It is a process through which curriculum stipulations are adapted to suit school goals, resources are secured, and the school generally monitors progress of implementation and evaluates the outcomes at specified stages in the implementation process.

Implementing the curriculum is the most crucial and sometimes the most difficult phase of the curriculum development process. This is because the final destination of any curriculum (whether it be a school, college, university or training organisation) is the classroom involving students, teachers, administrators and the community. Implementation takes place as the learner acquires the planned or intended experiences, knowledge, skills, ideas and attitudes that are aimed at enabling the same learner to function effectively in a society (University of Zimbabwe, 1995, 8). Effective implementation requires among other things, the involvement of parents in the education of their children.

Gonzalez-Mena (2011) defined parental involvement as a combination of commitment and active participation on the part of the parent to the school and child. Anyikwa and Obidike (2012) describe parental involvement as the participation and support of parents at school and in the home, which directly and positively impacts the educational performance of their children. It is the provision of curricular and co-curricular support by parents to promote effective learning for their school children. Parental involvement entails seeing parents as active collaborators in their own children's learning and development and ensuring that they are well informed about their children's school lives and clear about the ways in which they can work with the school (Williams \& Ullman, 2002). According to Chan (1995, 19), "parental involvement is not something that is 'done' to parents". It is rather what parents and the school do collectively and collaboratively to ensure adequate and effective policy making and implementation, discipline, funding, facilities and staffing for the success of children.

A large body of evidence demonstrates a strong and positive link between parents' involvement and interest in a child's learning and a child's subsequent adjustment and achievement (Ali, 2012; Curriculum for Excellence 2010; Reynolds, 2007; Sylva, Scott, Totsika, Ereky-Stevens \& Crook, 2008). Anyikwa and Obidike (2012) report that for children to maximize their potentials from schooling, they need the full involvement of their parents. The importance of parental involvement is further highlighted by Morrison (2007) who notes that parents' involvement in children's learning positively affects the children's performance at school. Similarly, Kindiki (2009) observes that when there is adequate parental involvement in their children's education, an increase in the children's academic motivation and achievement can be observed. When schools and parents work in partnership, students realize that people who take care of them in both environments are investing and coordinating time and resources to help them succeed. Studies have also established a direct and positive correlation between parental involvement and academic achievement or motivation (Crozier \& Reay, 2005; Henderson \& Berla, 1997). Cheeks (2012) adds that parental involvement in education, either in school or at home, creates partnerships among schools, parents, and communities. The resulting partnerships among students, parents, and teachers develop effective communication from home to school and school to home. Through active and ongoing communication, parents and teachers share information and resources regarding students' academic and behavioral conduct. Together, these efforts establish a solid foundation for both families and schools to help children succeed in school and in their future. On the other hand, proponents also suggest that part of the benefit of parental involvement in education in any situation is that doing so can result in positive change in homes, communities and the wider society (RSA, 2010; Scott \& Sylva, 2004; UNICEF, 2009). Either way, parental involvement can be seen as a dynamic avenue that can bring about change not only in schools and education systems, but also in homes and societies.

In line with the evidences of the gains of parental involvement in education, the Nigerian National Policy on Education (Federal Republic of Nigeria 2004) includes a mandate that requires that the local people particularly 
parents will be encouraged to participate in school management. Moreover, some reference to parent involvement was addressed in the following legislation concerning public school education: (a) Universal Basic Education Act 2004 (b) the Ten Year Strategic Plan 2005, and (c) Public Private Partnership (PPP) 2006 (Federal Ministry of Education, 2005, 2011; Obioma, 2005). These mandates speak directly to the Nigerian agendas of democratisation of schooling and citizen participation in public services including education. They also make the recognition of parental involvement the purview of Nigeria's education system. They present an opportunity for the development of a form of parental involvement that meets the complex and multiple needs of contemporary society, and a more localised and engaged education system.

The momentum to involve parents in education continued as schools wanted to better their school's environment and performance. This momentum to involve parents came as the result of poor schooling, poor academic achievement, and poor student conduct in and out of classroom settings. It was an understood belief that parent involvement not only improved a child's morale, attitude, and academic achievement across all subject areas, but it also promoted better behavior and social adjustment. In all these ways, parent and family involvement in education helped children to grow up to become productive, responsible members of society.

The National Parent-Teacher Association (PTA) (n.d) highlights 100 ways for parents to be involved in their children's education. The ways cover decision-making, influencing policy enactment and implementation, enforcing discipline, negotiating and collaborating in curriculum, supervision and monitoring of school processes, and providing staff, funds and facilities. Through these ways, the parental involvement provides a platform of developing good working relationship between the home and the school towards a fruitful upbringing of the children. It also help students develop the ability to think and reason, build self-respect and respect for others, and reach their full potential as individuals, members of their communities and citizens of the world. University of Zimbabwe (1995) speculates that the parents should provide schools with financial resources to purchase required curriculum materials; demand the inclusion of certain subjects in the curriculum; and influence learners to reject courses they consider detrimental to the interests of the group. As Edward and Lee (2009) assert, the involvement of the parents is crucial to enable children to achieve, at a minimum, the knowledge and skills prescribed in the curriculum.

\subsection{Importance of the Problem}

Although there is a burgeoning body of research on parents' participation in schools, these studies have focused on fundraising, provision of facilities and decision-making through Parents-Teachers association's meetings (Obi, 2003; Udemadu, 1991; UNICEF, 2001; Uzoechina \& Obidike, 2007). These studies revealed that parents have a lot to contribute to the funding, discipline, and other aspects of administration of schools. However, to the best of the researcher's knowledge, no study appears to have investigated the involvement of the parents in curriculum implementation as perceived by the principals in Anambra State of Nigeria thus creating a research gap. Besides, the educational mandates that call for parental involvement in education do not have a set of standards to guide the implementation of parental involvement in education. They lack a process, formal mechanism and benchmarks for assuming this task. Consequently, different schools adopt different policies and measures, and have different levels of parent involvement. Although school staff and policy makers alike intuitively accept the importance of parental involvement in schools; however, knowing how meaningfully the parents are involved in curriculum implementation for the benefit of all children is less understood. The problem of this study is therefore to determine, based on the perceptions of male and female principals, the extent to which parents are involved in curriculum implementation in secondary schools in Anambra State of Nigeria.

\subsection{Theoretical Framework}

The theoretical framework is derived from Epstein et al's (2002) model of parental involvement. Epstein et al. (2002) define parenting in six facets: parenting, communicating, volunteering, learning at home, decision making, and collaborating.

1) Parenting skills to assist parents with understanding their children's learning needs, and helping teachers understand family needs;

2) Communication that allows for two-way, open communication between the school and home;

3) Volunteering that recognizes parents' talents and contributions both in and for the school;

4) Learning at home strategies that engage the family with their children's school work;

5) Decision making that includes parents as key stakeholders in making decisions that will impact student learning; and 
6) Collaborating with the community to create mutual benefit by sharing resources and contributing to both school and community goals.

Parenting included the basic responsibilities of families, such as providing housing, health care, nutrition, clothing, and safety, as well as creating home conditions that support children's learning (e.g., purchasing necessary books and other school supply or providing a place to study). Parenting also implied that parents were warm and responsive to their children, communicated with them, and supported their development. The second most important factor in any partnership was communication. This type of involvement concerned the basic responsibilities of schools, including establishing two-way communication between family and school. Williams, Williams and Ullman (2002) note that communication between schools and parents remained a positive step in the right direction. Uzoechina and Obidike (2007) add that communication involving sharing information, empowering parents, dismantling barriers to understanding and cooperation, and recognizing parents' strengths, priorities, and perspectives is fundamental to building strong relationships between the home and the school. Communication provides opportunities for the exchange of information were vital and must be consistently utilized for meaningful involvement to occur among parents, teachers, and administrators.

Epstein et al. (2002) identify volunteering as the third approach to involvement. Volunteer usually referred to persons who devoted their spare time to working on a routine basis without monetary compensation, usually under the direction of a school employee, in support of educational activities and school operations. The authors clarified, however, that parental engagement in PTA or other types of decision-making organizations involving parents, teachers, and perhaps students and other community members, was not volunteering. Epstein et al. (2002) called the fourth step learning at home. This type of involvement suggested that parents were involved in curriculum-related activities occurring at home (e.g., assisting with homework, discussing books with their child, or brainstorming ideas for school projects). Parents who were involved at this level often advocated in the children's best interests. These parents often participated in PTA, advisory councils, and committees, which constituted the fifth step, decision making, in the Epstein et al. model.

Finally, collaborating with the community was the type of involvement that relied on understanding that helping the community was the best investment (Epstein et al., 2002). Through collaborations, different types of community organizations contribute to schools, students, and families. Sharing in Epstein's (1995) belief that parent involvement was essential, Goodall and Vorhaus (2011) a model of good practice Parental engagement requires active collaboration with parents and should be pro-active rather than reactive. Cheeks (2012) concluded that an increasing number of the general features of parental engagement strategies proposed by Epstein et al (2002) are supported by evidence derived from high quality research.

The present study is informed by previous research indicating the importance of parental involvement in all the areas listed by Epsten et al. (2002). However, whilst many of the specific activities required of parents and schools are less well supported, there is a dearth of literature on parental involvement in specific areas of the curriculum (Radd, 1993; Scott \& Sylva, 2004). As Goodall and Vorhaus (2011) observe, with the partial exception of numeracy, very little is known about parental involvement relating to other parts of the curriculum. It is difficult to draw conclusions about how parental involvement in curriculum is viewed by male and female principals. For instance, it is not clear whether male principals see the parents as being more involved than female principals see them and whether the areas of parental involvement differ based on the gender of the principals. A research gap thus exists as to what extent male and female principals as school administrators perceive the parents to be contributing to secondary schools curriculum implementation in the state. It is therefore worth comparing male and female principals of approximately the same working status as leaders of public schools in the present study.

\subsection{Research Question and Hypothesis}

The present study is guided by the following research question and hypothesis:

1) What is the extent of parental involvement in curriculum implementation in schools?

2) Is there any significant difference between the mean ratings of male and female principals on the extent of parental involvement to curriculum implementation?

\section{Method}

\subsection{Research Design}

A descriptive survey design was used in this study. The design was appropriate because it is useful in establishing the nature of existing situation and current conditions and also in analyzing such situations and 
conditions. It enabled the researcher to collect data from secondary school principals in order to identify their perceptions on parental involvement curriculum implementation in schools.

\subsection{Population and Sample}

Two hundred and fifty-seven principals of secondary schools constituted the population for this study. This population was made up of all the 112 male and 145 female principals of the 257 government-owned secondary schools in the state. Since the population was small, purposeful sampling technique was used to include all the principals owing to their ability as school leaders to understand issues of parental involvement and how it is carried out in their schools. There was no sampling rather the entire 257 principals comprising 112 male and 145 female principals participated in the study.

\subsection{Instrumentation and Procedure}

\subsubsection{Instrument for Data Collection}

The researcher constructed a questionnaire titled "Assessment of The Involvement of Parents in Secondary Schools Curriculum Implementation". The questionnaire had two parts. Part A contained an item on the gender of respondents. Part two comprised 16 items on parental involvement to curriculum implementation. All the 16 items were structured on a 4-point scale of great extent, great extent, low extent, and very low extent.

An open-ended structured interview was also used to elicit principals' opinions on parental involvement. The interview schedule comprised four core questions on the areas of curriculum that parents were involved in, the magnitude and the content of such involvement. The questions that formed the core of the interviews:

1) Do you think that parents of students in your school actively contribute to effective teaching of their children as expected by the school?

2) What particular practices related to curriculum and teaching do the parents do, to which you can ascribe the success of your school?

3) How would you describe the parents' involvement in their curriculum roles through the Parents-Teachers' Association? Are there any areas for improvement?

4) How would you describe the quantity of parents' curriculum involvement? Are there any areas for improvement?

\subsubsection{Validation and Reliability of Instrument}

Two experts in the Department of Educational Foundations (Curriculum Studies) from Nnamdi Azikiwe University, Awka validated the Instrument. They made some corrections which were affected in the final copy of the instrument. The test-re-test method was used to ascertain the reliability of the questionnaire items. This involved administering the copies of the questionnaire on five principals which were, not included in the final study. After two weeks, the same questionnaire was re-administered on the same respondents. Pearson Product Moment Correlation was used to correlate the two sets of scores. A reliability coefficient of 0.76 was obtained and considered satisfactory for the study.

\subsubsection{Method of Collection}

The researcher was helped by four research assistants in administering copies of the questionnaire to the principals. They retrieved the questionnaire copies after the principals filled them. The distribution and collection lasted for three weeks, at the end of which all the 257 copies $(100 \%)$ were collected back.

\section{Results}

\subsection{Statistics and Data Analysis}

The survey data was analyzed descriptively to facilitate the answering of the research question. The data was coded, organized and analyzed, with the aid of SPSS computer programme. The mean scores and standard deviations were determined for each item. The Mean scores were used in answering the research questions. Based on the 4-point rating scale, the mean of the scale is 2.5. The decision is that means scores equal to or above 2.5 are considered high extent whereas those below 2.5 are regarded as low extent.

Open-ended responses were analysed using a content analysis approach. After the researcher had completed the interview, she transcribed the data and read through all of the responses to become familiar with the content. Next, the researcher independently created a list of categories into which the responses seemed to fit and coded them using frequency and percentages.

In testing the hypothesis, the t-test was used at the 0.5 level of significance. The t-test was used to compare the 
opinions of male and female principals in order to determine of and significant difference exists between their mean scores.

\subsection{Presentation of Results}

The results of the study are presented in Tables using mean scores and the decision rule. A brief summary of results is presented after each table.

Table 1. Opinion of principals on parental involvement in curriculum implementation

\begin{tabular}{|c|c|c|c|c|}
\hline \multirow[t]{2}{*}{$\mathbf{S} / \mathbf{N}$} & \multirow[t]{2}{*}{ ITEMS } & \multicolumn{2}{|c|}{$\begin{array}{l}\text { Mean Scores } \\
\text { Principals }\end{array}$} & \multirow{2}{*}{ Decision } \\
\hline & & Males & Females & \\
\hline 1. & providing text books for students & 2.88 & 2.65 & Great extent \\
\hline 2. & requesting for extra lessons for students & 3.00 & 3.08 & Great extent \\
\hline 3. & contributing to educational film shows for students & 3.00 & 3.06 & Great extent \\
\hline 4. & $\begin{array}{l}\text { supporting schools efforts to integrate Information } \\
\text { and Communication Technology in the curriculum }\end{array}$ & 1.23 & 2.47 & Little extent \\
\hline 5. & engaging teachers for special subjects & 1.17 & 2.23 & Little extent \\
\hline 6. & $\begin{array}{l}\text { requesting teachers to provide referrals for students' } \\
\text { extra coaching in difficult subjects. }\end{array}$ & 2.67 & 2.78 & Great extent \\
\hline 7. & $\begin{array}{l}\text { ensuring that students do their take-home } \\
\text { assignments }\end{array}$ & 2.79 & 2.75 & Great extent \\
\hline 8. & $\begin{array}{l}\text { providing teaching and learning materials such as } \\
\text { wall charts, computers, television sets, radios, etc }\end{array}$ & 2.11 & 2.33 & Little extent \\
\hline 9. & $\begin{array}{l}\text { providing for visits to places of interest, e.g., zoos, } \\
\text { museums, centres, shopping and market places, etc. }\end{array}$ & 1.19 & 2.32 & Little extent \\
\hline 10. & $\begin{array}{l}\text { bringing information to the school about some } \\
\text { aspects of the school curricula that need review }\end{array}$ & 1.01 & 1.00 & Little extent \\
\hline 11. & $\begin{array}{l}\text { being involved in decisions on student placement } \\
\text { and course and textbook selections. }\end{array}$ & 2.11 & 2.47 & Little extent \\
\hline 12. & $\begin{array}{l}\text { attending parent-teacher meetings and asking } \\
\text { specific questions on school curriculum }\end{array}$ & 1.17 & 1.26 & Little extent \\
\hline 13. & $\begin{array}{l}\text { participating in informal opportunities to talk } \\
\text { with and get to know about subject syllabuses }\end{array}$ & 2.13 & 2.22 & Little extent \\
\hline 14. & $\begin{array}{l}\text { giving positive feedback and appreciating teachers } \\
\text { and the principal for effective curriculum delivery }\end{array}$ & 3.14 & 3.68 & Great extent \\
\hline 15. & $\begin{array}{l}\text { making appointments as needed to discuss students' } \\
\text { academic progress or concerns }\end{array}$ & 1.21 & 1.03 & Little extent \\
\hline \multirow[t]{2}{*}{16.} & $\begin{array}{l}\text { volunteering as experts or mentors from outside the } \\
\text { school to work alongside teachers during lessons }\end{array}$ & 0.21 & 0.66 & Little extent \\
\hline & Average Mean & 1.94 & 2.25 & Little extent \\
\hline
\end{tabular}

As shown in Table 1, only items six items (items) 1, 2, 3, 6, 7 and 14 score above 2.50 in the columns of male and female principals. This means that parents contribute to a great extent in the areas of curriculum implementation listed. The mean ratings for the remaining 10 items are less than 2.50 , which indicate that there is a little extent of parental involvement in those areas. The table has an average mean 1.94 and 2.25 respectively. The result shows that the principals perceived a little extent of P.T.A's involvement in curriculum implementation. 
Table 2. T-test on male and female principals' views on parental involvement in curriculum implementation

\begin{tabular}{llllllll}
\hline Gender & N & Mean & SD & DF & Cal t & Critical t & P \\
\hline Male principals & 112 & 1.94 & 1.31 & & & & \\
Female principals & 145 & 2.27 & 1.29 & 255 & 1.94 & $\mathbf{1 . 9 6}$ & $\mathbf{0 . 0 5}$ \\
\hline
\end{tabular}

Table 2 shows that $t$-calculated value is 1.94 while the critical-t value is 1.96 with 255 degrees of freedom and 0.05 level of significance. Since the calculated $t$ exceeds the critical $t$, the null hypothesis is therefore accepted and the conclusion is that there is no significant difference between the mean ratings of male and female principals on the extent to which parents are involved in schools' curriculum implementation.

\section{Discussion of Findings}

The finding of the study indicates that the parents are involved to schools' curriculum implementation only to a little extent. In fact, it is only in provision of textbooks, requesting for extra lessons for students, contributing for educational film shows, discussing students' academic activities with staff, ensuring the students do their take-home assignments as well as giving positive feedback and showing appreciation for teachers and the principal for effective curriculum implementation that the parents are involved. There is a low extent of parental support for schools' ICT integration in the curriculum. Given Jing and Zhou's (2012) finding that parental support is significantly positively associated with technology self-efficacy, interest in technology, perceived importance of the Internet, and perceived impact of the Internet on learning, the present finding is worrisome. Such low involvement in ICT-Curriculum integration is likely to hinder the schools and their students from using ICT in curriculum delivery.

Other areas of involvement in curriculum implementation expected from the parents such as supporting technology integration into the curriculum, engaging teachers for special subjects, providing learning resources, sponsoring excursions, and bringing information to the school about some aspects of the school curricula, are rated to a little extent. Further, there is a low extent of parental involvement in decisions on student placement and course and textbook selections, attending parent-teacher meetings and asking specific questions on school curriculum, participating in informal opportunities to talk with and get to know about subject syllabuses as well as making appointments as needed to discuss students' academic progress or concerns. A little extent of parental involvement as mentors is also evident. Such mentoring would have enhanced curriculum implementation because as Westminster Institute of Education (2006) notes, mentors could provide students with extra intellectual stimulus, introduce unusual elements that are not normally covered, or mediate in the use of alternative or new resources.

This finding disagrees with UNICEF (2001) who at the end of four country studies (China, India, Indonesia and Thailand) on parent-teacher cooperation reports that, parents participated extensively in curriculum development where they serve as advisory council members, curriculum committees, and classroom supervisors, thereby participating in joint problem solving of the school at all levels. The finding is also contrary to the assertion by National (n.d) that the either as a group or as individual parents should not only create a conducive environment; they should also provide learning facilities such as charts, computer units, television sets, radios, magazines and the like. UNICEF (2009) further states that for effective learning, parents should participate in curriculum implementation in schools by providing for visits to places of interest, eg, zoos, museums, local craft centres, shopping and market places, enrolling the child in extra lessons, discussion of school courses, and other students' class work with teachers. These activities are supportive to child's effort to learn thereby enhancing performance and increasing the educational horizons. For the parents to neglect these areas might limit effective learning among students.

Data from the open-ended questions is more revealing. It is clear the $83.29 \%$ of the principals $(\mathrm{N}=214)$ do not perceive the parents as active participants in the curriculum delivery process as expected by the school. Only $16.71 \%$ (43) principals are of the opinion that the parents actively participate in curriculum delivery. Within the content of the involvement, four areas of parents' involvement are indicated by the principals as being of importance to the success of the school. These areas are monitoring homework, requesting teachers to provide referrals for students' extra coaching in difficult subjects, complaining to principals about teachers' ineffective teaching, and urging principals to do more to ensure that students pass examinations. Just as Reynolds (2007) observes, the parents place higher priority in the academic activities than other involvement activities. As one of the principals put it: 
The parents are particularly interested in having their students pass examinations. To most of them, paying money is the chief concern. Whenever you invite them to discuss about how they could assist to help their children learn for instance by guiding their children to read supplementary texts on concepts slated in the syllabus, they would argue that since they have bought the textbooks being used in classes, there is no need for any supplementary text. If you invite them to school to discuss with the teachers, they would say they have no time. Rather they would keep mounting pressure on the school to mount extra lessons at extra costs for their children.

Another principal gives an example of a parent who was summoned to the school to discuss his child's academic progress, the parent accused the principal and teachers of wasting his time because the principals and teachers were either too lazy to teach his son or intentionally allocating fail grades to his son. The parent believed that his duty was to pay the child's school fees, buy the recommended textbooks and pay all levies for instructional materials and or extra lesson. If after fulfilling his role the child still had academic problems, then the school had failed. Even when the issues bothering on curriculum delivery was raised during Parents-Teachers' Association's (PTA) meetings, which only a few parent endeavour to attend, the parents present would always say that the parents' duty was to pay fees and that the duty of the principals and teachers are to deliver the curriculum.

Within the context of discussions on parents' participation in PTA meetings, all the principals express dismay at the attitude of parents to PTA meeting. They reveal that many parents do not attend PTA meetings. And if there are fines or levies attached to absenteeism at such meeting, a good number of the parents would rather send their "house-helps" to represent them. The question then is "What meaningful contribution would those housekeepers make to effective curriculum delivery in schools? Could they really serve as meaningful substitutes for parents with respect to students' learning needs?"

In the light of the open ended interviews, it appears that apart from issues associated with money and material, many parents do not demonstrate both the interest and the capacity to work substantively with schools on curriculum delivery. There is a high level of parental indifference to curriculum delivery. This finding supports that of Chang (1995) that many parents, who did not see the need and the merits of involvement activities, had little participation in the educational process even the PTA offered them the opportunities.

Another emergent issue from the open ended discussion is that the principals themselves lack knowledge of what parental involvement in curriculum actually entails. When asked to describe the quantity of parents' curriculum roles, many of the principals are quick to say that the quantity is inadequate and unsatisfactory. However when requested to identify specific areas of improvement, they most common area is that parents should provide resources and materials to build parent. This is followed swiftly by "monitor their children at home and make sure they study". One of principals mentions that "parents that are teachers should teach their children at home". And another says "parents should always supervise their children's school work and report any observation of teacher incompetence to the principal". Two hundred and forty-two (94.16\%) of the principals believe that the parents cannot not volunteer because they lack knowledge and time to do so. In addition, they argue that they have competent teachers, already assigned to classes; hence, having parents as volunteers would interfere with school structures.

When asked about parent's involvement in decision-making related to curriculum, all the participating principals indicate that the parents are not professionals in the field and would not know what to contribute. They also point out that parents cannot contribute to the curriculum delivery because the curriculum and its implementation guidelines are centrally developed without specifications on how parents should be involved. This implies unwillingness on the part of the principals to involve parents in curriculum decision-making. Further, two hundred and thirteen principals $(82.88 \%)$ accept that parents could only volunteer as organizers of some school activities, and guests to give prizes during such activities. In other words, the principals lack confidence in the ability of some parents to participate in curriculum delivery. This observation concurs with the argument that in an era of budgetary constraint for schools and other public services, the resource offered by local stakeholders, including parents and families, but also employers, cultural organisations and so on, is invaluable to, but frequently underutilized by schools (RSA, 2010).

It was also found out that there was no significance difference between the mean ratings of male and female principals on the extent of parental involvement in curriculum implementation. This indicates that irrespective of gender, the principals in this study hold a similar view of a little extent of parental involvement to curriculum implementation in schools. Epstein, Sanders, Simon, Salinas, Jansorn, and Van Voorhis (2002) adduce two reasons for such low involvement as parents' lack of familiarity with curriculum issues and lack of awareness among principals and teachers of how to effectively involve parents in curriculum implementation. Low extent 
of parental involvement in curriculum implementation could also be because as Quinn (2002) points out, some principals find it difficult to provide curriculum leadership in a manner that would inspire parental involvement because of the loss of certain satisfying rituals such as coaching teachers and demonstrating expertise to a class, activities that in spite of making workload more onerous, have always made direct instructional leadership so personally rewarding. Another reason might also because many parents do not appear to value their role in their child's education. Whatever the reason is, the point remains that both male and female principals rated as making low involvement to curriculum implementation.

What the findings of this study means is that the parents have relegated their roles in the academic development of their children. This situation has the tendency to hinder effective learning among students and effective curriculum implementation among teachers. It is important to note Sylva, Scott, Totsika, Ereky-Stevens \& Crook's (2008) speculation that the relationship between behaviour problems and reading difficulties in curriculum starts before school due to poor parental involvement. They also imply that children who go on to develop reading difficulties often have behaviour problems at the beginning of school, and these lead on to poor reading performance, which could be corrected through collaboration of parents and teachers.

\section{Implications of Findings for a Framework for Parental Involvement in Curriculum Delivery}

The study findings have implications for a framework for improved parental participation in curriculum delivery. The implications are developed and illustrated as in figure 1:

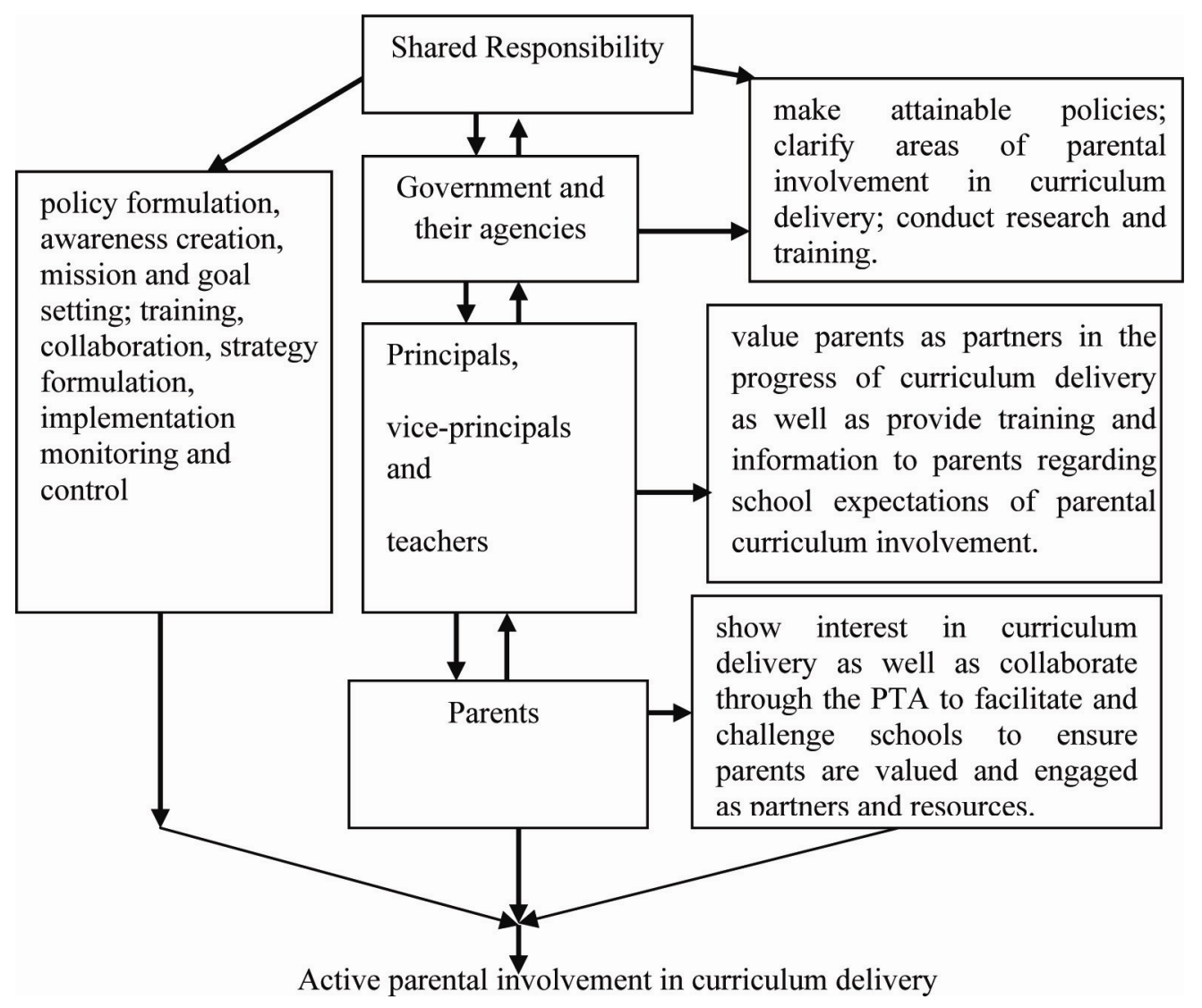

Figure 1. A framework for improved parental involvement in curriculum delivery

This framework indicates that improved parental involvement in curriculum delivery, there has to a shared responsibility in the areas of policy formulation, stakeholder to be involved and specific roles of each category of stakeholder. The arrows pointing downwards from shared responsibility imply that government and their agencies, school staff, and parents should be involved in their various capacities. They will achieve this by policy-making, awareness creation, strategy formulation, implementation and monitoring of parental involvement initiatives. Similarly, under shared responsibilities, the manners in which these stakeholders will share their responsibilities are depicted by the arrows leading from each group to their specific responsibilities. 
The arrows that point upwards show that parents, principals and school staff as well as government and its agencies should work collaboratively towards a two way process of parents being involved as resources for learning within the school. Government should mandate schools in clear terms on how and where to involve parents in curriculum delivery, periodically train school staff and parents in those areas and provide incentives, provide a benchmark for assessing parental involvement in curriculum delivery, and conduct research on effective school-parent partnerships. School staff (principals, vice-principals and teachers should honour parents by validating any level of involvement or contributions they make; organize parent/teacher/student conferences or student-led conferences as effective mechanisms for curriculum delivery, raise consciousness and build school-family skills, commitment, remove practical barriers, recognize contributions and provide incentives and make an attempt to learn about parents' strengths, skills, talents, and experiences. They should also change organizational processes and culture, and help to increase parent knowledge of curriculum, provide regular feedback to parents on curriculum issues, students' progress and resource needs and foster school-community relationship. On their own part, parents should provide resources, monitor their wards, and volunteer in school events; develop good relationship with principals and teachers; keep school well informed about homework, curriculum problems and child development; attend school events, help in the classroom, ask questions about curriculum and syllabus; and provide goof home environment and teach their children in school and at home. They should further involve themselves not only in terms of funds or parental rights, but to be good, responsible parents, attend PTA meetings and make suggestions on curriculum delivery and facilitate school community relationships. All these are in line with the imperative for schools and parents to succeed in engaging parents with children's learning because of the clear impact on attainment this has on learning (Francis, 2011). The linking arrows at the end of the diagram indicate that these activities are collectively needed and must work together for effective parental involvement in curriculum delivery in secondary schools.

The present finding therefore highlight the need for addressing this issue of low extent of parental involvement in curriculum implementation. There is a need for schools and parents to collaborate for effective curriculum implementation. Parental involvement requires the engagement of all parents, and collaboration should: be pro-active rather than reactive, sensitive to the circumstances of all families, recognise the contributions parents can make and aim to empower parents. Future studies should develop a robust repertoire of strategies for increased parental involvement in curriculum implementation.

\section{Conclusions and Recommendations}

The purpose of curriculum implementation at any level is to bring about desirable changes in the learners as specified by the curriculum. These changes may be in skills, knowledge, abilities, concept formation, tackling of problems and attitudes. Effective curriculum implementation requires the concerted efforts of schools and associations especially the Parents. This study have shown that in the opinions of secondary school principals in Anambra state of Nigeria, the parents make very little involvement to curriculum implementation.

For this trend to improve, the school principals and teachers need to make efforts for reaching and involving parents in positive ways. They should design and implement strategies that will result in improved parental involvement, and at the same time, balance parental involvement vis-à-vis educators' professional autonomy. Principals should make more efforts to mobilize the parents towards participating in schools' curriculum implementation. Seminars and meetings of teachers, administrative functionaries and parents at the state level will have to be arranged. The parents should be sensitized by principals and teachers during meetings and conferences on the need for their interest in schools' curriculum implementation and sponsoring schools' extracurricular activities. They should help parents understand why their involvement in curriculum implementation is so important to their children's school success. When improved, parental involvement would become a strategy for the enhancement of academic quality and continuous improvement in the learning opportunities and experiences offered by schools.

\section{References}

Ali, M. (2012). The shadow of colonialism on relations between immigrant parents and their children's teachers. Alberta Journal of Education, 53(2), 198-215.

Anyikwa, N., \& Obidike, N. (2012). Mothers' constructions of their roles in the literacy education of their children. Africa Development, 36(3), 57-67.

Chan, W. (1995). The impact of the Parent-Teacher Association (PTA) on a secondary school in Hong Kong. Unpublished Dissertation University of Hong Kong.

Cheeks, M. (2012). The impact of learning centers as a parent-involvement aid to improve student success. 
Unpublished Doctor of Education Dissertation. Nova Southeastern University Florida: Abraham S. Fischler School of Education.

Crozier, G., \& Reay, D. (Eds.). (2005). Activating participation: Mothers, fathers and teachers working towards partnership. VA: Stylus Publishing

Curriculum for Excellence. (2010). Curriculum for excellence in action: Bringing life to learning and learning to life. Retrieved November 18, 2013, from http://www.curriculumforexcellenceScotland.gov.uk

Department for Education. (2010). The school curriculum. Retrieved November 18, 2013, from http://www.education.gov.uk/ schools/teachingandlearning/curriculum

Desforges, C., \& Abouchaar, A. (2003). The impact of parental involvement, parental support and family education on students achievement and adjustment: A Literature Review. London: Department for Education and Skills.

Edwards, G., \& Lee, J. (2009). Leading curriculum change for education for sustainable development in schools. Schooling for Sustainable Development, 1, 95-114. http://dx.doi.org/10.1007/978-1-4020-9686-0_5

Epstein, J. L., Sanders, M. G., Simon, B. S., Salinas, K. C., Jansorn, N. R., \& Van Voorhis, F. L. (2002). School, community, and community partnerships: Your Handbook for Action (2nd ed.). Thousand Oaks, CA: Corwin Press.

Esu, A. E. O. (2005). Capacity building curriculum in Nigeria. Journal of the World Council for Curriculum and Instruction, 5(2), 1-7.

Ezekwesili, O. (2006). An institutional framework for effective coordination and implementation of reform policies between Federal and State Government. Retrieved October 6, 2007, from http://www.reasons.opinion.ng

Federal Ministry of Education. (2005). Ten year strategic plan. Lagos: Federal Ministry of Education.

Federal Republic of Nigeria. (2004). National policy on education (4th ed.). Abuja: Nigeria Educational Research and Development Council (NERDC) Press.

Federal Republic of Nigeria. (2011). Road map for education in Nigeria. Abuja: Federal Ministry of Education

Francis, B. (2011). “(Un)satisfactory?” Enhancing life chances by improving satisfactory schools. London: RSA

Gatawa, B. S. M. (1990). The politics of the school curriculum: An introduction. Harare: Jongwe Press.

Gonzalez-Mena, J. (2011). Foundations of early childhood education: Teaching children in a diverse setting. New York: McGraw-Hill.

Goodall, J., \& Vorhaus, J. (2011). Review of best practice in parental engagement. Research Report DFE-RR156 London: Department for Education.

Henderson, A. T., \& Berla, N. (1997). A new generation of evidence: The family is critical to student achievement. Washington, DC: Center for Law and Education.

Jing, L., \& Zhou, J. (2012). Digital divide: How do home internet access and parental support affect student outcomes? Education (Basel), 2, 45-53.

Kindiki, J. (2009). Effectiveness of boards of governors in curriculum implementation in secondary schools in Kenya. Educational Research and Reviews, 4(5), 260- 266.

Lawson, M. (2003). School-family relations in context: Parent and teacher perceptions of parent involvement. Urban Education, 38(1), 77-133. http://dx.doi.org/10.1177/0042085902238687

Morrison, G. S. (2007). Early childhood education today. Upper Saddle River, New Jersey: Pearson Merrill Prentice Hall.

National PTA. (n.d.). 100 ways for parents to be involved in their child's education. Retrieved September 22, 2013, from http://www.pta.org

Nnadozie, J. C. (2004). Evaluating curriculum relevance in Nigeria's educational system. In H. O. N. Bosah, C. O Obiagwu, \& K. A. Azubuike (Eds.), Refocusing Nigerian education system for the nascent democracy (pp. 24-60). Benin: daSylva Influence limited.

Obi, E. (2003). Educational management. Enugu: Jamoe Enterprises.

Obioma, G. O. (2005). The 9-year basic education curriculum (structure, contents and strategy for 
implementation. Nigeria's experience in educational reform. Retrieved May 31, 2009, from http://www.udesa.edu.ar/files/EscEdu/Inclusi\%C3\%B3n\%20Educativa/39\%20Godswill\%20Obioma\%20(N igeria).pdf

Oluniyi, O., \& Olajumoke, G. (2013). Curriculum development in Nigeria: Historical perspectives. Journal of Educational and Social Research, 3(1), 73-83.

Ornstein, A., \& Hunkins, F. (1998). Curriculum: Foundations, principle and issues. Boston, MA: Allyn \& Bacon.

Quinn, D. M. (2002). The impact of principal leadership behaviours on instructional practice and student engagement. Journal of Educational Administration, 40(5), 447-467. http://dx.doi.org/10.1108/09578230210440294

Radd, T. (1993). Restructuring parent-teacher organizations to increase parental influence on the educational process. Elementally School Guidance and Counselling, 27(4).

Reynolds, J. (2007). Parents' involvement in their children's learning and schools: How should their responsibilities relate to the role of the state? Bristol: Policy Press.

RSA Projects. (2010). Engaging the local: The RSA Area Based. Curriculum. London: RSA.

Scott, S., \& Sylva, K. (2004). The SPOKES project: Supporting parents on kids' education. Researcher' summary. In D. Quinton (Ed.), Supporting Parents: Messages from Research. London: Jessica Kingsley Publishers.

Sowell, E. (2000). Chapter 1: Overview of curriculum processes and products. In Curriculum: An integrative introduction. Upper Saddle River, NJ: Prentice-Hall.

Tanner, D., \& Tanner, L. (1995). Curriculum development: Theory into practice (3rd ed.). Englewood Cliffs, NJ: Merrill.

Thomas, L. (2012). Re-thinking the importance of teaching: Curriculum and collaboration in an era of localism. London: RSA

Udemadu, T. N. (1991). A case study of the role of parents-teachers association in the administration of secondary schools in Onitsha urban. Unpublished undergraduate thesis. Nnamdi Azikiwe University, Awka.

UNICEF. (2001). Parental involvement in high school management: Views from the field. Retrieved April 13, 2007, from http://www.utas.edu.au/universitycouncil/plans_structure/ict.pdf

UNICEF. (2009). Chapter 4: School and community child friendly schools. Retrieved November 18, 2013, from http://www.unicef.org/devpro/files/CF5Manual_ch04_052009.pdf

University of Zimbabwe. (1995). Curriculum implementation, change and innovation. (Module EA3AD 303). Harare: Centre for Distance Education, University of Zimbabwe.

Uzoechina, G., \& Obidike, N. (2007). Parental involvement in primary education in Anambra State: The way forward. Journal of childhood and primary education, 2(1), 101-106.

Westminster Institute of Education. (2006). What do we mean by enrichment. Oxford: Brooks University.

Williams, B., Williams, J., \& Ullman, A. (2002). Parental Involvement in Education. London: Queen's Printer.

\section{Copyrights}

Copyright for this article is retained by the author(s), with first publication rights granted to the journal.

This is an open-access article distributed under the terms and conditions of the Creative Commons Attribution license (http://creativecommons.org/licenses/by/3.0/). 